\title{
Effect of storage time on the biodegradability of olive oil mill wastewater from the cold extraction of olive oil system
}

\author{
Zakia Gueboudji ${ }^{1,2,+}$, Mohamed Bagues ${ }^{3,,+}, K_{\text {Kenza Kadi }}^{1,2}$, Kamel Nagaz $^{3}$, Dalila Addad ${ }^{2}$
}

\begin{abstract}
The olive oil processing industry's liquid effluents (OMW) have a polluting capacity for the ecosystems. This study aimed to evaluate the physicochemical quality of OMW of two varieties of separated and combined olives cultivated in Khenchela Eastern Algeria, from the cold extraction of the olive oil extraction system. These was to determine their degree of pollution and biodegradability during one year of storage at ambient temperature to recommend the correct treatment for each storage time. Results of the measured parameters $\mathrm{pH}$, EC,TSS percent, $\mathrm{H}_{2} \mathrm{O}$ percent, lipids, DM, OM, MM, VM, COT percent, NTK percent, $\mathrm{C} / \mathrm{N}, \mathrm{BOD}_{5}, \mathrm{COD}, \mathrm{BI}, \mathrm{TOM}, \mathrm{BOD}_{5} / \mathrm{COD}$ show that wastewater from olive oil mills has an acid $\mathrm{pH}$, and they are very loaded with organic matter evaluated in terms of $\mathrm{COD}$ and $\mathrm{BOD}_{5}$, quite filled with minerals. The storage of olive mill waste can reduce progressively the pollution caused by this waste. Whereas during one year, the reduction rate of COD, $\mathrm{BOD}_{5}, \mathrm{TOM}, \mathrm{BI}$, is respectively $29.4 \%, 54.8 \%, 39.16 \%, 54.2 \%$, but $\mathrm{C} / \mathrm{N}, \mathrm{BOD}_{5} / \mathrm{COD}$ continue to increase as well as $\mathrm{pH}$ that continues to decrease during the storage. Accordingly, storing olive mill waste during a year reduces its pollution rate, so it is slowly biodegradable. When disposing of it, an adequate treatment procedure must be required to protect the environment.
\end{abstract}

Keywords: physicochemical parameters, biodegradability, OMW, cold extraction, storage time.

${ }^{1}$ Biotechnology, Water, Environment and Health Laboratory, Abbes Laghrour University of Khenchela, Algeria.

${ }^{2}$ Faculty of Natural and Life Sciences, Abbes Laghrour University of Khenchela, Algeria. ${ }^{3}$ Drylands and Oases Cropping Laboratory, Institute of Arid Regions of Medenine, University of Gabes, Tunisia.

${ }^{*}$ Corresponding author: M. Bagues

E-mail: bagues007@gmail.com

+ This author's contributed equally to this work.

DOI: 10.2478/ebtj-2021-0023

(C) 2021 Authors. This work was licensed under the Creative Commons Attribution-NonCommercialNoDerivs 4.0 License.

\section{Introduction}

The olive industry is a very important economic activity in Mediterranean countries (1), including Algeria, where the olive tree is one of the most planted plants. This agriculture is concentrated in the country's north, especially in mountainous areas (2). In addition to the production of olive oil during each season, this activity generates two kinds of waste. The first is a solid called olive pomace, and the second is a liquid called olive oil mill wastewater (OMW) or vegetation water (3). The composition of OMW is more variable. This variable is affected by the quality of the olives their level of ripeness, the extraction system, and the quality of the water added during the oil recovery stage (4). Recovery applications and assessments have adopted the physicochemical properties of treated wastewater. The variation of these characteristics is determined by the variety of olive, geographical and climatic conditions, fertilizer use, and process of pressing olives $(4,5)$. The major waste product from the extraction of olive oil in heavily polluted acidic liquid form is OMW. Because of the presence of tannins and phenolic compounds of low molecular weight (6, 7 ), it has an extreme purple-brown or brown-red to black appearance and an olive oil odor. Its composition is variable and complex, primarily consisting of sugars, lipids, polyalcohols, proteins, organic acids and polyphenols (8). It is considered as one of the most contaminated and hazardous food industry residues to the environment (9), especially from producing countries (10). This is due to its diverse organic structure, vast quantity, and complexity in treating, as well as the lack of practicable or cost-effective OMW treatments $(5,11)$. Therefore, it must be disposed of by dumping it immediately into the air, most often in waste streams, storing it in evaporation ponds, or spreading it out to the 
ground, resulting in soil blockage, surface and ground water pollution, and the release of unpleasant odors. Much of this has a detrimental impact on the environment $(12,13,14)$, as he has recently noticed. Every year, there is a rise in olive production and the establishment of mills as a result of increased use of olive oil due to its health benefits (15). This increase in production leads to an increase in waste, particularly when comparing modern techniques for extracting olive oil to older techniques (16). It entails an uptick in emissions and significant environmental disruption. The toxicity of OMW is mostly due to their high content of non-biodegradable organic matter, which makes them resistant to natural degradation (17). Annual volumes of olive pomace is estimated to be 180,000 tons; a ton of olives yields 450 liters of OMW under traditional pressure and 600 to 1200 liters under modern pressure (18). For many years, the primary goal of much research has been to reduce the polluted effects of OMW by identifying appropriate alternatives and treatment approaches. They have embraced and improved a wide range of relevant approaches and technologies, including thermal treatments (19), physicochemical treatments (20), biological treatments (21), and physical treatments (22) and evaporation ponds, which are still the most commonly used technique due to their simplicity $(12,16)$. However, although all of the procedures and approaches that have been tested and evaluated for OMW treatment have proved to be technically reliable, they can not be used because they are prohibitively costly.

Before conducting or experimenting with any waste treatment, physicochemical analyses are required to know its properties in order to select the most appropriate method of treatment, and this is to avoid having a negative impact on the environment rather than solving the problem (23). In this study, we attempted to determine the effect of storage time on the biodegradability of OMW in three different samples (Zlitni, Abani varieties, and bi-varietal mixture 50\%-50\%) from the cold extraction system of olive oil in Khenchela, Algeria's northeastern region.

\section{Materials and Methods \\ Origin of the olive mill wastewaters}

During the olive harvest season, OMW fresh sampling was conducted in a modern cold extraction oil mill where the extracting temperature does not exceed $25^{\circ} \mathrm{C}$, located in Baghai, Khenchela (3531'19 “N, 76'52” E, 886m a.s.l.) in northeastern Algeria (January 2019). The samples were taken from the liquid effluent collection tank immediately just after olive press, put in clean plastic cans rinsed with the OMW to be tested, and then closed without any alteration or treatment. They were stored at room temperature in the dark. Each analysis is carried out three times.

Different parameters were examined at different storage times: t0: time just after olive oil extraction, $\mathrm{t} 1(1 \mathrm{M})$ : one month of storage, $\mathrm{t} 2(2 \mathrm{M})$ : two months of storage, $\mathrm{t} 3(6 \mathrm{M})$ : six months of storage, and $\mathrm{t} 4(12 \mathrm{M})$ : twelve months of storage.

\section{Physicochemical parameters}

Seventeen (17) physicochemical parameters were studied, including $\mathrm{pH}$, electrical conductivity EC, lipid content, water content $\left(\mathrm{H}_{2} \mathrm{O} \%\right)$, dry matter (DM), total suspended solids (TSS\%), organic matter (OM), mineral matter (MM), volatile matter (VM), total organic carbon (TOC), total kjeldalh nitrogen $(\mathrm{TKN}), \mathrm{C} / \mathrm{N}$, biological oxygen demand $\left(\mathrm{BOD}_{5}\right)$, chemical oxygen demand (COD), total oxidizable matter (TOM), biodegradability index $(\mathrm{BI})$, and $\mathrm{BOD}_{5} / \mathrm{COD}$.

\section{$\mathrm{pH}$}

The $\mathrm{pH}$ was measured directly in the sample using a $\mathrm{pH}$ meter form (AdwaAD1000) with pH buffer solutions 4, 7, and 10, according to Rodier's method (24).

\section{Electrical conductivity (EC)}

It was measured following the method of Rodier (24), for samples filtered and centrifuged without making a dilution, using a conductivity meter type (inoLab WTW). The results were expressed in millisiemens per centimeter $(\mathrm{mS} / \mathrm{cm})$.

\section{Lipid content}

Following the method of D'Annibale et al. (21), lipid content was determined gravimetrically after hexane extraction. $20 \mathrm{~mL}$ of OMW was mixed with $30 \mathrm{~mL}$ of $\mathrm{n}$-hexane, the mixture was vigorously mixed with a vortex type (VELP scientifica ZX3) in a $100 \mathrm{~mL}$ separating funnel, then centrifuged in a centrifuge type (SIGMA 2-16K) for $5 \mathrm{~min}$ at $3000 \mathrm{t} / \mathrm{min}$. The three-hexane phases were combined and the solvent was evaporated at $79^{\circ} \mathrm{C}$ in a rotary evaporator type (HAHNSHIN SCIENTIFIC$\mathrm{CO})$, dried at $100^{\circ} \mathrm{C}$ in an oven and then cooled in a desiccator for $30 \mathrm{~min}$. The drying was repeated until a content weight is obtained. The results were expressed in percent (\%).

\section{Water content $\left(\mathrm{H}_{2} \mathrm{O} \%\right)$}

According to the method of Gortzi et al. (25), it was measured by drying at $105^{\circ} \mathrm{C}$ for 24 hours in an oven model (memmert) and weighting the difference between the dry and wet samples. The results were expressed in percent (\%).

\section{Dry matter DM}

The dry matter rate was determined by the weight difference between the OMW (100\%) and the content $\left(\mathrm{H}_{2} \mathrm{O} \%\right)$.

\section{$\mathrm{DM} \%=100 \%-\% \mathrm{H}^{2} \mathrm{O}(25)$.}

The results were expressed, after applying the rule of three, as grams per liter $(\mathrm{g} / \mathrm{L})$.

\section{Total suspended solids TSS (\%)}

The total suspended solids (TSS \%) were obtained according to the method of Assas et al. (26) after drying overnight at 105 ${ }^{\circ} \mathrm{C}$ and then weighing (AFNOR NF T90-105). The results were expressed in percent $(\%)$.

\section{Organic matter (OM)}


The content of organic matter was obtained by deduction between the dry weight of the OMW and its weight after calcination (mineral matter) (27). The results were expressed as grams per liter $(\mathrm{g} / \mathrm{L})$.

\section{Mineral matter (MM)}

It was performed according to Pauwels et al. (27). The dry OMW sample was calcined in a muffle furnace type ( $\mathrm{Na}$ bertherm) at $550{ }^{\circ} \mathrm{C}$, for 24 hours. After cooling in a desiccator, the ashes were weighed and constitute the mineral matter.

We calculated it according to the formula: $\mathrm{MM}=(\mathrm{M} 2-\mathrm{M} 0) /$ V x 1000, with:

MM: ash content (g/L), M0: empty capsule mass (g),

M2: capsule mass with calcined dry matter $(\mathrm{g}), \mathrm{V}$ : volume of the test sample $(\mathrm{ml})$.

The results were expressed as grams per liter $(\mathrm{g} / \mathrm{L})$.

\section{Volatile matter (VM)}

It was determined by making the difference between the dry matter obtained and the ash residue from calcination at $550{ }^{\circ} \mathrm{C}$ in a muffle furnace for $24 \mathrm{~h}$. It was expressed in $\mathrm{g} / \mathrm{L}$ relative to the dry weight (27). The results were expressed as grams per liter $(\mathrm{g} / \mathrm{L})$.

\section{Total organic carbon (TOC)}

It was determined according to AFNOR standard AFNOR T90-110 (28). It was determined from the rate of organic matter using the formula:

TOC $\%=\% O M / 1.725$

The results were expressed in percent (\%).

\section{Total Kjeldahl Nitrogen (TKN)}

It was determined according to AFNOR standard AFNOR T90-110 (28), using the Kjeldahl method with some modifications. Introduce $5 \mathrm{~mL}$ of raw OMWW with $7.5 \mathrm{~g}$ catalyst $(\mathrm{CuSO} 4+\mathrm{K} 2 \mathrm{SO} 4)$ and a little selenium in a matrass. Add 10 $\mathrm{mL}$ of $\mathrm{H} 2 \mathrm{SO} 4$ and $10 \mathrm{~mL}$ of oxygenated water $30 \%\left(\mathrm{H}_{2} \mathrm{O}_{2}\right)$ as anti-foaming. Put some glass balls as shockproof.

Heat to a temperature of $100{ }^{\circ} \mathrm{C}$ for a while to prevent the foam from overflowing and continue heating until it disappears and the contents are charred. Then increase the mineralization temperature to $400{ }^{\circ} \mathrm{C}$ until the appearance of a clear and limpid green coloration, continue heating for $30 \mathrm{~min}$ then let cool. Distillation was done using soda (32\%) and distilled water in an automatic distillation apparatus. The distilled ammonia is trapped in an Erlenmeyer flask containing $20 \mathrm{~mL}$ of boric acid $4 \%$, then quickly titrate with sulfuric acid (H2SO4) (N/50) up to the initial $\mathrm{pH}$ of boric acid. The nitrogen level was calculated according to the following formula:

$\% \mathrm{~N} 2(\mathrm{~g})=\left(\mathrm{V} 1{ }^{\star} 0.014^{\star} 100^{\star} \mathrm{N}\right) / \mathrm{V} 0$

$\mathrm{N}$ : normality of the sulfuric acid $\mathrm{N} / 50$.

V0: sample volume in $\mathrm{ml}(5 \mathrm{~mL})$.

$\mathrm{V} 1$ : volume in $\mathrm{ml}$ of the sulfuric acid solution used for the titration.

The results were expressed as grams per liter $(\mathrm{g} / \mathrm{L})$.

\section{Carbon to nitrogen mass ratio $(\mathrm{C} / \mathrm{N})$}

Determined by method of AFNOR (29). The carbon to nitrogen ration is an indicator of the ability of an organic product to decompose more or less quickly in the soil.

$\mathrm{C} / \mathrm{N}>25$ : Microorganisms will draw on soil reserves instead of releasing them.

$\mathrm{C} / \mathrm{N}<25$ : Microorganisms will release excess nitrogen available to plants.

\section{Biological oxygen demand $\left(\mathrm{BOD}_{5}\right)$}

It was determined following the method of Rodier (24), using a BOD meter type (VELP Scientifica) in a thermostatically controlled enclosure type (AQUA LYTIC) for the biological oxygen demand $\mathrm{BOD}_{5}$ (AFNOR T90-103). The results were expressed as grams per liter $(\mathrm{g} / \mathrm{L})$.

\section{Chemical oxygen demand (COD)}

The chemical oxygen demand COD is determined on raw OMW samples according to the AFNOR NF T90-101 standard, using a COD meter type (VELP Scientifica), using potassium dichromate as described by Rodier (24). The results were expressed as grams per liter $(\mathrm{g} / \mathrm{L})$.

\section{Total oxidizable matter (TOM)}

It constitutes the main part of the biodegradable part of the organic pollution released; it was determined by calculating the formula (24):

TOM $(\mathrm{g} / \mathrm{L})=\left(2 \mathrm{BOD}_{5}+\mathrm{COD}\right) / 3$

The results were expressed as grams per liter $(\mathrm{g} / \mathrm{L})$.

\section{Biodegradability index (BI)}

It was determined by calculating the ratio of $\mathrm{COD} / \mathrm{BOD}_{5}$, an indicator of the importance of pollutants with little or no biodegradation (24).

$\mathrm{BI}=\mathrm{COD} / \mathrm{BOD}_{5}$ If: B I> 6: Hardly biodegradable substrate $3<\mathrm{BI}<6$ : Partially (or less easily) biodegradable substrate $\mathrm{BI}<3$ : Very easily biodegradable substrates.

\section{$\mathrm{BOD}_{5} / \mathrm{COD}$ ratio}

An index that gives an idea of the level of pollution presented by the liquid effluents.

BOD/COD > 0.5: effluent treatable by biological processes.

$0.2<\mathrm{BOD} / \mathrm{COD}<0.6$ : feasibility of treatment using selected microbial strains.

$\mathrm{BOD} / \mathrm{COD}<0.2$ : biological treatment impossible (30).

\section{Statistical analyses}

All data was analyzed by two-ways ANOVA. Correlations between some parameters were determined using Pearson's simple correlation test. Means were compared using Duncan's test at $p<0.05$ level of significance by means of SPSS 20 for Windows. The principal Components Analysis (PCA) test was performed using XLSTAT software version 2014.5.03 (Addinsoft). 


\section{Results}

\section{Effect of the genotype, time, and their interaction on} the measured parameters

The analysis of variance (Table 1) showed the existence of a very highly significant genotype effect on the measured parameters ( $\mathrm{pH}, \mathrm{EC}$, Lipids, TSS, Water, DM, VM, TKN, C/N, COD, $\mathrm{BOD}_{5}$, and TOM) with $(\mathrm{P}<0.001)$, significant on $\mathrm{MM}$ with $0.01<\mathrm{p}<0.05$. Additionally, the time effect was also highly significant on all of the measured parameters ( $\mathrm{pH}, \mathrm{EC}$, Lipids, TSS, Water, DM, VM, TKN, C/N, COD, BOD, MM, BI, TOM, and $\left.\mathrm{BOD}_{5} / \mathrm{COD}\right)$ with $(\mathrm{p}<0.001)$ and excepted for the two parameters OM, TOC showed a significant effect at $0.001<\mathrm{p}$ $<0.01$.
The decrease rates of the Zlitni, combination, and Abani varieties were $1.68,1.88$, and 2.03 units, respectively. A comparison of average values revealed that the Zlitni variety was more acidic than the mixture and the Abani variety, with values of (4.40, 4.42, and 4.82, respectively).

\section{Effect on electrical conductivity}

The electrical conductivity of the samples decreased after 12 months of storage (Fig. 1). EC was lowered by $90.82 \%, 87.15 \%$, and $84.7 \%$ for the Abani, Zlitni, and combination, respectively. The average values registered for Abani, the combination, and Zlitni are $14.72,14.33$, and $12.83 \mathrm{mS} / \mathrm{cm}$, respectively.

Table 1. Results of variance analysis of the genotype effects, time and their interaction on some measured parameters

\begin{tabular}{|c|c|c|c|c|c|c|c|}
\hline ANOVA & $\mathrm{pH}$ & $\mathrm{EC}$ & $\mathrm{COD}$ & $\mathrm{BOD}_{5}$ & BI & TOM & $\mathrm{BOD}_{5} / \mathrm{COD}$ \\
\hline Genotype (G) & $* * *$ & $* * *$ & $* * *$ & $* * *$ & ns & $* * *$ & ns \\
\hline Time (T) & $* * *$ & $* * *$ & $* * *$ & $* * *$ & $* * *$ & $* * *$ & $* * *$ \\
\hline G x T & $* * *$ & $* * *$ & * & ns & ns & * & ns \\
\hline Error & 0.000 & 0.000 & 432.822 & 118.803 & 0.092 & 142.061 & 0.004 \\
\hline
\end{tabular}

ns, not significant, ${ }^{\star},{ }^{* \star},{ }^{* * *}$ significant at $\mathrm{p}<0.05, \mathrm{p}<0.01$, and $\mathrm{p}<0.001$, respectively.

There was a highly significant interaction effect $(\mathrm{G} \times \mathrm{T})$ on the calculated parameters $(\mathrm{pH}, \mathrm{EC}$, Lipids, Water, and $\mathrm{DM})$ with $(\mathrm{p}<0.001)$. This interaction had a significant effect to $0.001<\mathrm{p}<0.01$ on TSS and to $0.01<\mathrm{p}<0.05$ significant effect on the parameters (MM, TKN, COD and TOM).

The $(\mathrm{G} \times \mathrm{T})$ correlation, on the other hand, had no impact on the calculated parameters $(\mathrm{VM}, \mathrm{OM}, \mathrm{TOC}, \mathrm{C} / \mathrm{N}, \mathrm{BI}$, and $\left.\mathrm{BOD}_{5} / \mathrm{COD}\right)$. For the varieties Zlitni, Abani, and their combination, the means of the calculated parameter BI demonstrated a very highly important relationship with storage time. Consequentially, it was insignificant for the genotype effect and the relationship ( $\mathrm{G} \times \mathrm{T})$.

At first overview, the OMW tended to have a reddish-brown coloration, which darkened with storage, with a cloudy look and heavy smell reminiscent of olive oil, which become stronger with storage time.

The physicochemical properties of OMW were done basically by the variety and the extraction system. Table 1 showed the average compositions of the wastewater from the Zlitni and Abani types, as well as their mixture, used in this study. The mean effect of genotype, time, and their interaction on lipid contents, TSS percent, and MM revealed 11 groups, water content 14 groups, DM 13 groups, MV and C/N 10 groups, OM 4 groups, TOC 5 groups, and TKN 12 groups.

\section{Effect on $\mathrm{pH}$}

The obtained results revealed that the $\mathrm{pH}$ values of the three samples increased gradually over a period of 12 months of storage (Fig. 1).

\section{Effect on lipid content}

During 12 months storage period, the lipid content of Zlitni, Abani, and the mixture decreased by $96.95,88.93$, and $95.34 \%$, respectively. The OMW analyzed was low in lipids. According to a comparison of average values, the fattest rich OMW were those of variety Abani rather than the mixture, and the lowest is Zlitni, with the average values registered being (1.58, 1.44, and $1.33 \%$ ).

\section{Effect on TSS\%}

TSS values lowered by $33.67,32.45$, and $28.71 \%$ after 12 months of storage for Zlitni, Abani, and the mixture, respectively. According to the results obtained, the effluents studied were not very high in TSS. The average values received, sorted from most charged to least charged, were Abani (1.02\%), the combination (0.91\%), and Zlitni (0.91\%) (0.87\%).

\section{Effect on water content}

The water content gradually increased over 12 months storage period. The average was rising by $18.13,19.38$, and $18.56 \%$ for Zlitni, Abani, and the combination, respectively. The average values derived from more or less charge of water are 89.38, 88.86 , and $88.48 \%$ for Zlitni, the combination, and Abani, respectively.

\section{Effect on dry matter}

During 12 months of storage, dry matter content decreased gradually. It was decreased by $85.65,83.68$, and $88.03 \%$ for Zlitni, Abani, and the combination, respectively. The results 
indicated that the effluents were high in dry matter. The Abani variety had the highest average value, followed by the mixture and then Zlitni, with the following values $(117.17,111.43$, and $107.7 \mathrm{~g} / \mathrm{L})$.

\section{Effect on organic matter}

Organic matter reduced by $3.86,5.03$, and $4.14 \%$ with a storage period of 12 months for Zlitni, Abani, and the mixture, respectively. According to the findings, the OMW was loaded with organic matter. The three sample mixtures, Abani and Zlitni, had almost the same content with the following average values (82.44, 81.61, and 81.98 g/L).

\section{Effect on mineral matter}

Mineral matter slowly degraded over 12 months storage period. For Zlitni, Abani, and the mixture, the decreasing rates were approximately $24.57,29.90$, and $33.45 \%$, respectively. For the three samples, the values observed during the analysis were nearly identical. The average values obtained for Abbani, the mixture, and Zlitni are 23.07, 22.86, and $21.85 \mathrm{~g} / \mathrm{L}$, respectively.

\section{Effect on volatile matter}

The results obtained showed that volatile matter decreased by $96.08,93.13$, and $97.40 \%$ during 12 months storage period for Zlitni, Abani, and the mixture, respectively. Furthermore, the OMW tested were very high in volatile matter, demonstrating the organic origin of OMW. The average values were $(70.49 \mathrm{~g} / \mathrm{L}$ from Abani, $66.20 \mathrm{~g} / \mathrm{L}$ from Zlitni, and $65.56 \mathrm{~g} / \mathrm{L}$ from the mixture, respectively).

\section{Effect on NTK}

During 12 months storage period, the NTK content decreased. It was reduced by $29.60 \%$ for Zlitni, $43.50 \%$ for Abani, and $41.17 \%$ for the combination, respectively. According to the findings, OMW samples were very high in nitrogen. It registered the highest values in the mixture of the two varieties, then Abani and Zlitni with average values of $(2.20,1.90$, and 1.71 $\mathrm{g} / \mathrm{L}$, respectively).

\section{Effect on TOC \%}

TOC $\%$ decreased by 3.85, 5.03, and $4.15 \%$ after 12 months of storage for Zlitni, Abani, and the mixture, respectively. The results indicated that the TOC content was high in the liquid effluents tested. In all three experiments, we founded almost identical results. The order's average values are 47.79, 47.31, and $47.52 \%$ from the mixture, Abani, and Zlitni, respectively. Effect on $\mathrm{C} / \mathrm{N}$

According to the results obtained, the rate in this ratio increased gradually with the duration of 12 months of storage. Zlitni, Abani, and the mixture all increased by $46.55,68.12$, and $62.64 \%$, respectively. In addition, the Zlitni variety had the highest average value (28.77), followed by Abani (26.19) and then the mixture (22.56).

\section{Effect on $\mathrm{BOD}_{5}$}

During 12 months storage period, $\mathrm{BOD}_{5}$ values declined by 40.65, 48.38, and 46.42\% for Zlitni, Abani, and the Mixture, respectively.

The studied OMW had important $\mathrm{BOD}_{5}$ values, indicating that they are highly filled with biologically oxidizable organic matter. The average values revealed that the OMW of the mixture is higher $(93.59 \mathrm{~g} / \mathrm{L})$ than $(81.92 ; 62.27 \mathrm{~g} / \mathrm{L})$ for Abani and Zlitni, respectively.

\section{Effect on COD}

COD values gradually decreased during storage, indicating that organic matter was degrading. The decreasing rates for Zlitni, Abani, and the Mixture, respectively, were 71.18, 71.11, and $69.53 \%$.

According to the findings, the OMW analyzed had a very high oxygen demand for total oxidation of organic matter. The highest average values were found in the mixture $(237.87 \mathrm{~g} / \mathrm{L})$, Abani (209.8 g/L), and Zlitni (157.8 g/L), in that order.

\section{Effect on BI}

The implications of this ratio indicated the significance of low or biodegradable pollutants. According to the findings (Fig. 4), this ratio decreased steadily with storage time by $50.58,43.40$, and $43.13 \%$ for Zlitni, Abani, and the mixture, respectively. Furthermore, BI was almost identical in all three samples. The average values found are (2.43), (2.46), and (2.48) from Zlitni, the mixture, and Abani, respectively.

\section{Effect on TOM}

The results showed that oxidizable matter degrades during storage time (Fig. 5). TOM values for Zlitni, Abani, and the Mixture decreased by $59.90 \%, 62.22 \%$, and $60.40 \%$, respectively, from t0 to 4 . Moreover, TOM was included in a large amount of the OMW samples studied. The average values were higher in the mixture (141.68 g/L), Abani (124.55 g/L), and Zlitni $(94.11 \mathrm{~g} / \mathrm{L})$, in that order.

\section{Effect on $\mathrm{BOD}_{5} / \mathrm{COD}$}

We showed that this ratio improved over the period of 12 months of storage (Fig. 6). This average raised by $110.34,78.12 \%$ for Zlitni, Abani, and the mixture, respectively. The values revealed that this ratio was almost identical in all samples. The average values obtained in the order were Zlitni (0.44), Abani (0.43), and the mixture (0.43). Multivariate analysis (PCA).

The search for links between the genotypes of the water resources and their parameters measured during their storage (after time of 0, 1 month, 2 months, 6 months and 12 months) was studied through to the main PCA component analysis (Fig. 2). The projection of the variables (the parameters) and of the individuals (the genotypes) was carried out on the two axes which represent $88.17 \%$ of the total variance. The first two axes hold respectively $78.51 \%$ and $9.66 \%$ of information. Axis 1 integrated the information provided by most of the measured parameters (pH, EC, Lipids, TSS, DM, VM, TKN, COD, BOD , $\mathrm{MM}, \mathrm{BI}, \mathrm{TOM}, \mathrm{OM}$ and TOC) of the Zlitni varieties, Abani 


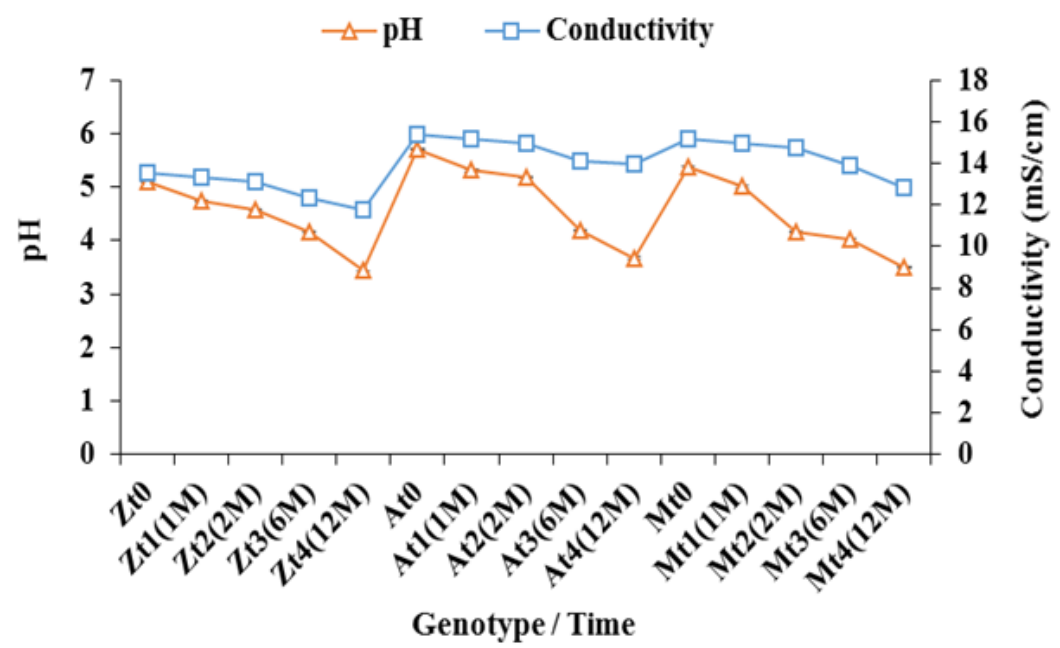

Figure 1. Linear regression representing the $\mathrm{pH}$ and $\mathrm{EC}$ of the tested OMWs within time of the storage. Z, A, and M correspond to Zlitni, Abbani, and Mixture, respectively. t0, t1 (1M), t2(2M), t3(6M), and t4(12M) correspond to different storage time.

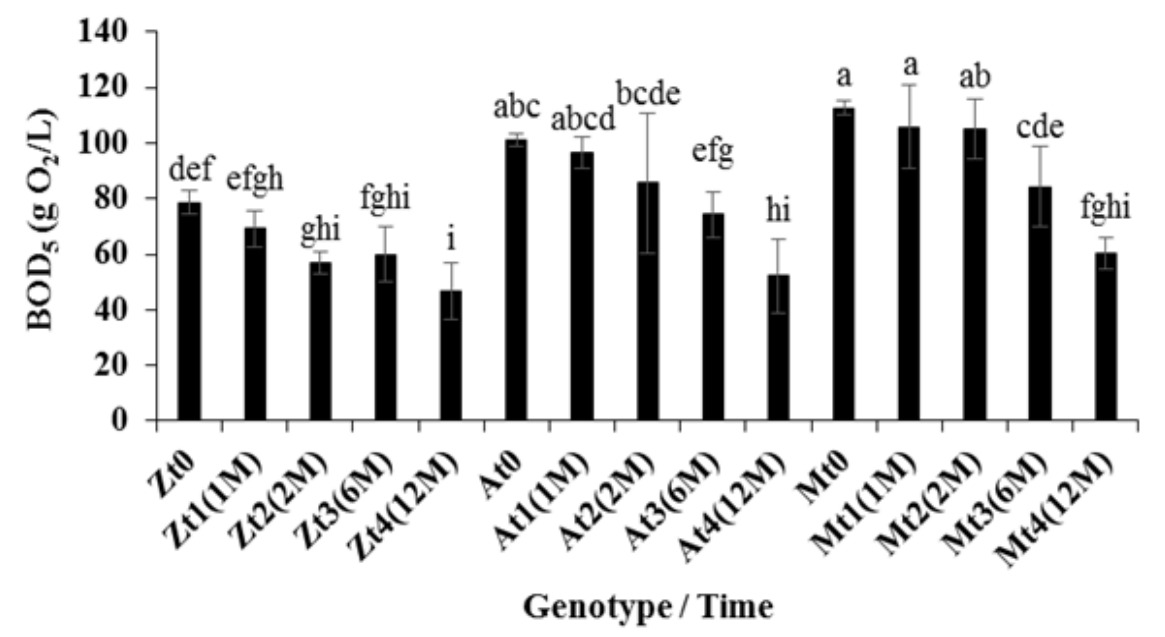

Figure 2. Effect of interaction ( $\mathrm{Gx}$ T) on $\mathrm{BOD}_{5}$ of the tested OMWs and their homogenous groups. Z, A, and M correspond to Zlitni, Abbani, and Mixture, respectively. $\mathrm{t} 0, \mathrm{t} 1(1 \mathrm{M}), \mathrm{t} 2(2 \mathrm{M}), \mathrm{t} 3(6 \mathrm{M})$, and $\mathrm{t} 4(12 \mathrm{M})$ correspond to different storage time. Column values with different letters are significantly different at $\mathrm{p}<0.05$, according to Duncan's multiple range test.

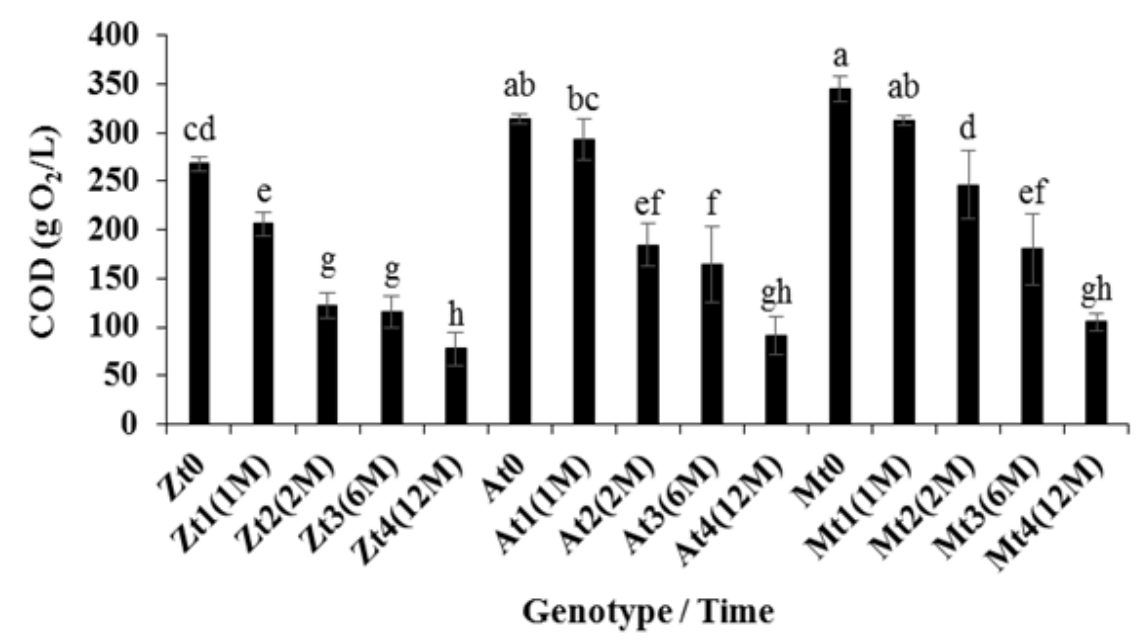

Figure 3. Effect of interaction ( G x T) on COD of the tested OMWs and their homogenous groups. Z, A, and M correspond to Zlitni, Abbani, and Mixture, respectively. $\mathrm{t} 0, \mathrm{t} 1(1 \mathrm{M}), \mathrm{t} 2(2 \mathrm{M}), \mathrm{t} 3(6 \mathrm{M})$, and $\mathrm{t} 4(12 \mathrm{M})$ correspond to different storage time. Column values with different letters are significantly different at $\mathrm{p}<0.05$, according to Duncan's multiple range test. 


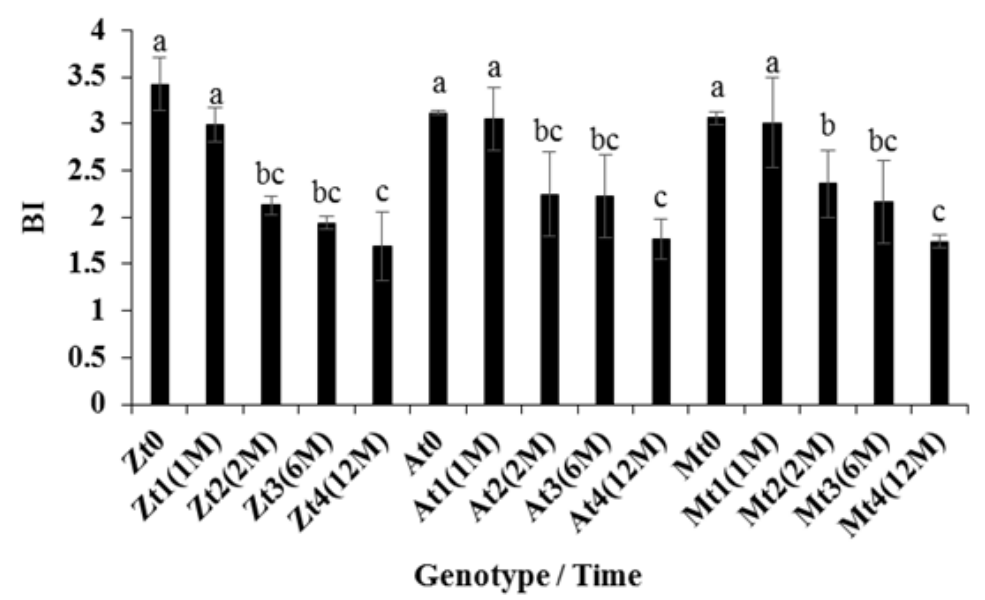

Figure 4. Effect of interaction ( $\mathrm{G} \times \mathrm{T}$ ) on BI of the tested OMWs and their homogenous groups. Z, A, and M correspond to Zlitni, Abbani, and Mixture, respectively. $\mathrm{t} 0, \mathrm{t} 1(1 \mathrm{M}), \mathrm{t} 2(2 \mathrm{M}), \mathrm{t} 3(6 \mathrm{M})$, and $\mathrm{t} 4(12 \mathrm{M})$ correspond to different storage time. Column values with different letters are significantly different at $\mathrm{p}<0.05$, according to Duncan's multiple range test.

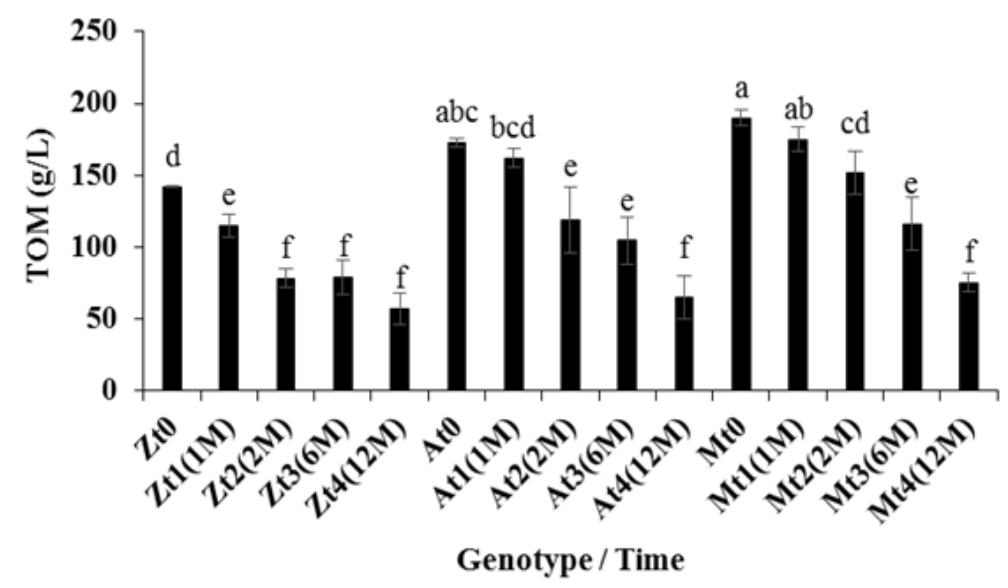

Figure 5. Effect of interaction ( $\mathrm{G} \times \mathrm{T}$ ) on TOM of the tested OMWs and their homogenous groups. Z, A, and M correspond to Zlitni, Abbani, and Mixture, respectively. $\mathrm{t} 0, \mathrm{t} 1(1 \mathrm{M}), \mathrm{t} 2(2 \mathrm{M}), \mathrm{t} 3(6 \mathrm{M})$, and $\mathrm{t} 4(12 \mathrm{M})$ correspond to different storage time. Column values with different letters are significantly different at $\mathrm{p}<0.05$, according to Duncan's multiple range test.

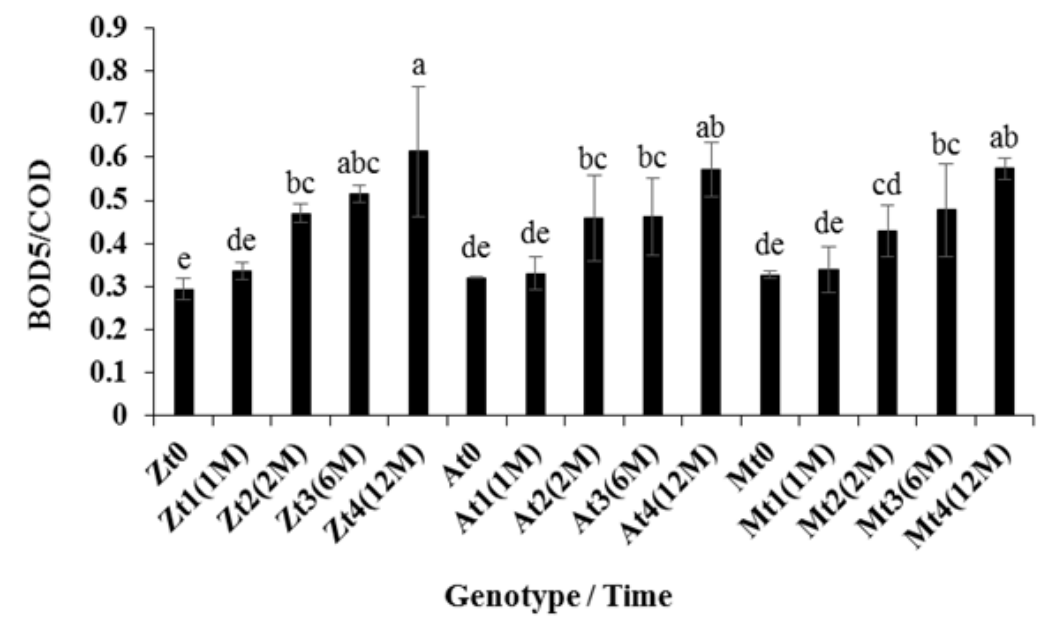

Figure 6. Effect of interaction $(\mathrm{Gx} \mathrm{T})$ on $\mathrm{BOD}_{5} / \mathrm{COD}$ of the tested OMWs and their homogenous groups. Z, A, and M correspond to Zlitni, Abbani, and Mixture, respectively. $\mathrm{t} 0, \mathrm{t} 1(1 \mathrm{M}), \mathrm{t} 2(2 \mathrm{M}), \mathrm{t} 3(6 \mathrm{M})$, and $\mathrm{t} 4(12 \mathrm{M})$ correspond to different storage time. Column values with different letters are significantly different at $\mathrm{p}<0.05$, according to Duncan's multiple range test. 


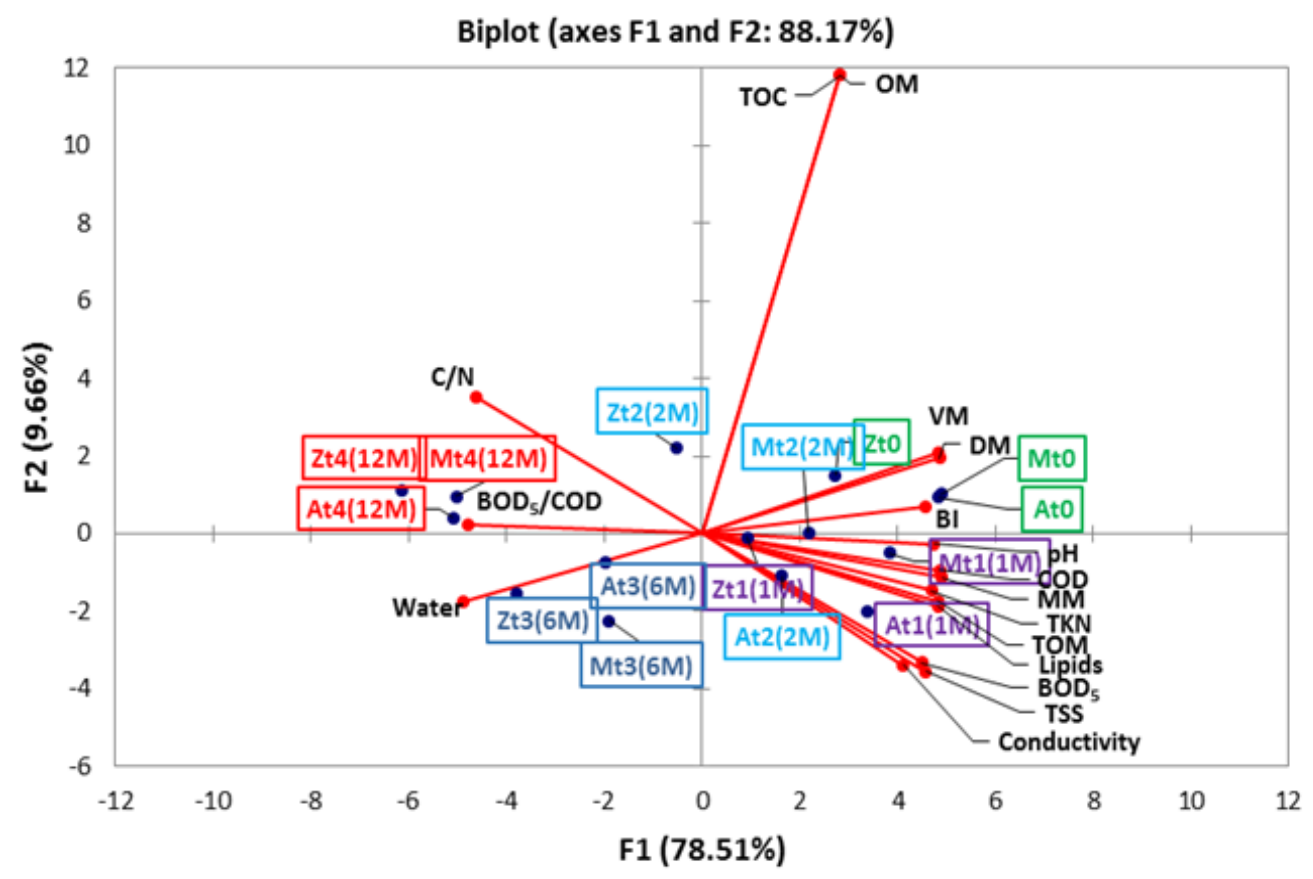

Figure 7. Projection of the interaction (time, genotypes and parameters measured on the plane $(1 \mathrm{x} 2)$ of the principal component analysis (PCA). Z, A, and M correspond to Zlitni, Abbani, and Mixture, respectively. t0, t1(1M), t2(2M), t3(6M), and t4(12M) correspond to different storage time.

and their mixture after 0 months, 1 month and 2 months of their storage $(\mathrm{t} 0, \mathrm{t} 1, \mathrm{t} 2)$. These parameters were positively correlated with this axis. The group composed exclusively of VM, $\mathrm{DM}$, and BI parameters of the varieties tested in addition to their mixture and measured immediately after sampling was positively correlated to axes 1 and 2 of the PCA. In addition, it was opposed along these two axes of the PCA and to the group consisting of the water parameter measured after 6 months of storage varieties tested with their mixture. Axis 2 of the PCA integrated the information provided by two groups. The third group had a positive correlation with this axis (2) and a negative correlation with axis 1 . This group included the two parameters $\mathrm{C} / \mathrm{N}$ and $\mathrm{BOD}_{5} / \mathrm{COD}$ of the varieties Zlitni, Abani, and their mixture, which were determined after one year (12 months) of storage. This group was opposed along this axis to the group composed of the parameters (pH, EC, Lipids, TSS, DM, VM, TKN, COD, $\mathrm{BOD}_{5}$, MM, BI, TOM, OM, and TOC) of the Zlitni varieties, Abani, and their mixture, which were measured after one month of storage (t1) and were positively correlated with axis 1 and negatively correlated with axis 2 .

The decrease in parameters (pH, EC, Lipids, TSS, DM, VM, TKN, COD, $\mathrm{BOD}_{5}, \mathrm{MM}, \mathrm{BI}, \mathrm{OM}, \mathrm{TOM}$, and TOC) of Zlitni and Abani varieties and their mixture are positively correlated with storage time and was extreme after 6 and 12 months. On the other hand, the parameter $\mathrm{BOD}_{5} / \mathrm{COD}$ increased during storage, indicating that this increase is positively correlated with time, as it gave higher values after 6 and 12 months, as explained.

\section{Discussion}

The rate of biodegradability of OMW was not constant during the storage time because OMW, due to their organic and mineral charges, provided a favorable medium for the survival of microorganisms. Microorganisms that consume it with the oxygen dissolved in this liquid effluent discover the organic matter. Furthermore, changes promote and affect microbial habitat, while organic degradation with a various enzymatic activities was already in progress $(31,32)$.

The OMW occurred as a reddish-brown to black aqueous and viscous residual liquid with a heavy olive odor. It comprised a diverse range of organic and mineral compounds of varying composition and concentration. This heterogeneity was primarily the product of the following factors: olive-ripening stage, soil and climate conditions, variety of olives, cropping system, duration and storage conditions of the olives before crushing, olive oil extraction process, which represents the most determining factor (33).

$\mathrm{pH}$ findings were consistent with those in other studies $(16,23,34,35,36)$. According to the literature, the presence of organic acids (37) and fatty acids such as palmitic acid, oleic acid, linoleic acid, and arachidonic acid (38), as well as sugar fermentation (39) and auto-oxidation and polymerization reactions that transform phenolic alcohols to phenolic acids (16). These reactions were manifested by a modification in the OMW's initial coloration to a very dark black color (40). Indeed, our effluents get a reddish-brown color that darkens significantly during storage. As a result, microbial reactions, oxidation, and fermentation probably induced the significant decrease in $\mathrm{pH}$ during storage.

The importance of $\mathrm{pH}$ was critical for the growth of mi- 


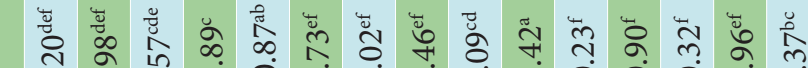

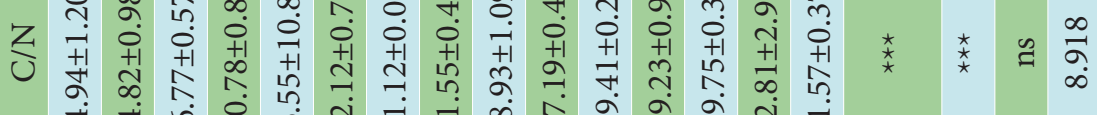
में

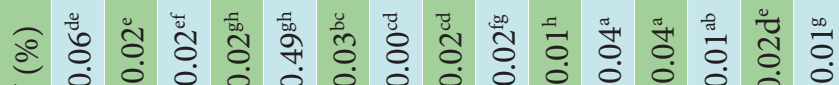

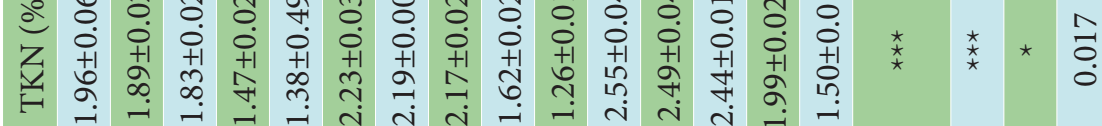

ఏई

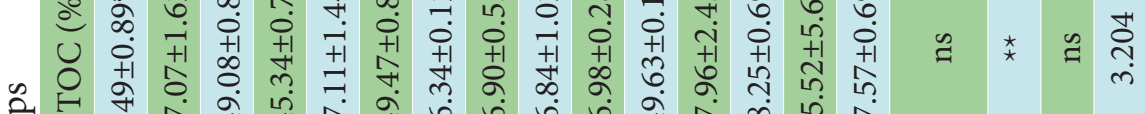

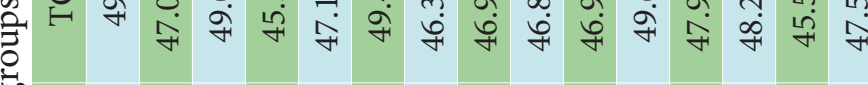

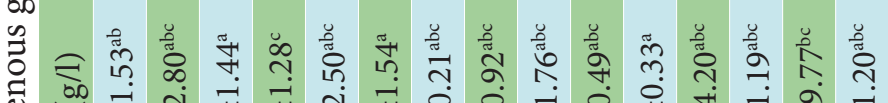

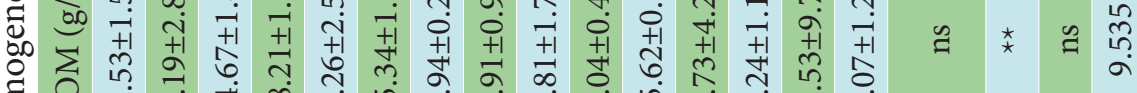

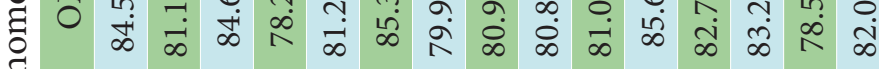

चี $\approx$ 華

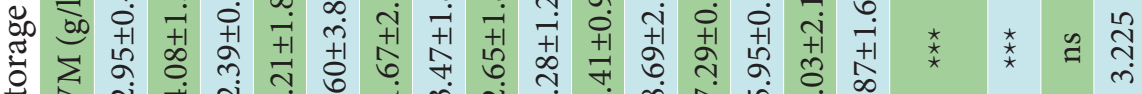

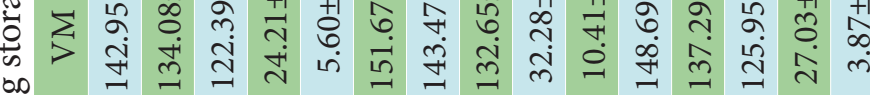
$\stackrel{\infty}{:}$

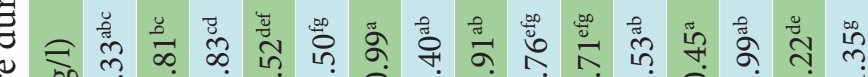

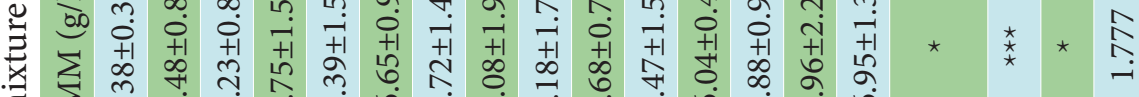

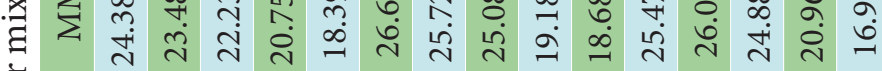

:

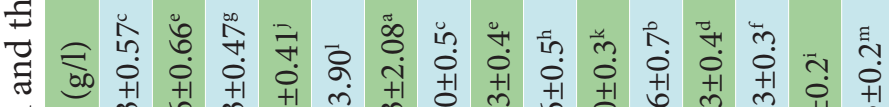

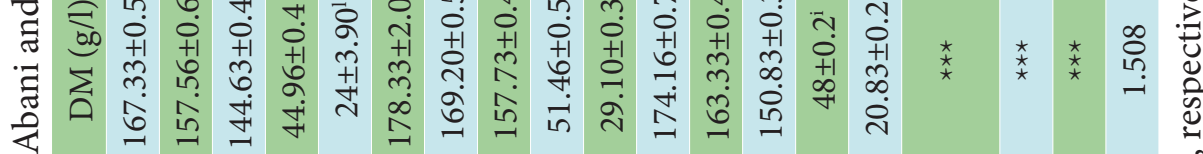

言

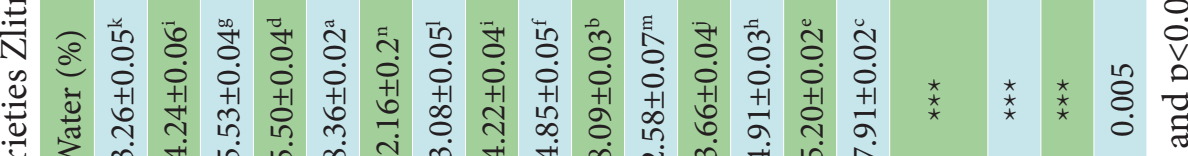

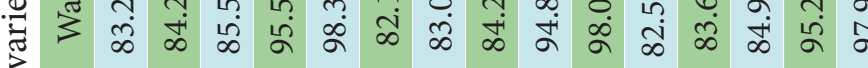
$\cong$

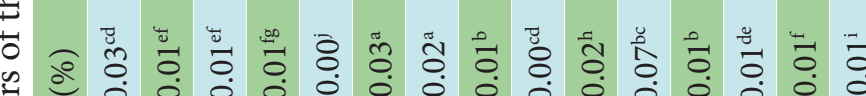

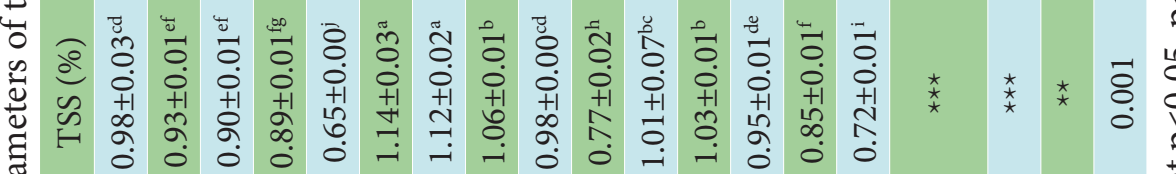

च ङ

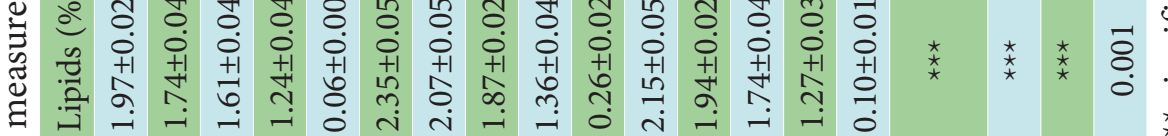
幽

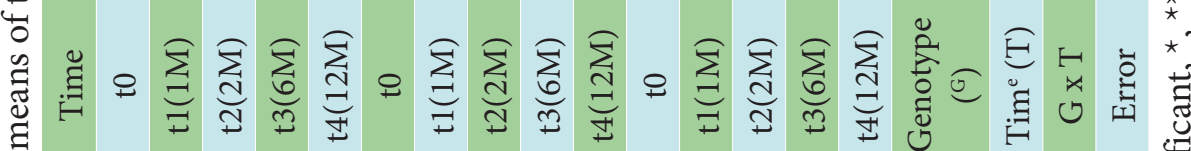
$\stackrel{\square}{\rightleftarrows}$

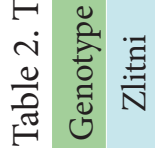


croorganisms, which had an optimum $\mathrm{pH}$ range of 6.5 to 7.5. When the $\mathrm{pH}$ was less than 5 or greater than 8.5 , the growth of microorganisms was directly inhibited, making biological treatment of raw OMW very complicated (16).

For the electrical conductivity, the obtained results showed that the OMW had a high electrical conductivity due to the rich mineral load (12). Our results were consistent with those of Zaier et al. (23) (EC = 11-13 mS/cm), Ouabou et al. (35) (EC $=16.14 \mathrm{mS} / \mathrm{cm})$, and Belaid et al. $(34)(\mathrm{EC}=15-15.1 \mathrm{mS} / \mathrm{cm})$. This disparity in electrical conductivity was due to the normal mineral salt content of olives $(9,20)$.

According to Achak et al. (9), conductivity was closely related to the quantity and composition of dissolved substances. In the case of OMW, this conductivity ranged between 18 and 50 $\mathrm{mS} / \mathrm{cm}$. The decrease in electrical conductivity rate with storage time may be attributed to the activity of bacteria qualified as prototrophs degrading the mineral elements in OMW.

The lipid level in OMW, in general, ranging from $0.03 \%$ to $4.25 \%$ in the literature. The findings agreed with those of many other researchers, including Kapellakis et al. (10) (lipids $=0.5-2.3 \%)$ and Esmail et al. (16) (lipids = 1-2.5\%), Benamar et al. (14) (0.03-1.1\%), and Mohawesh et al. (11). (0.97\%). The level of lipids present in OMW was determined by the olive oil extraction system.

When opposed to the conventional method, the centrifugation process produces low rates. The difference in lipid content is due to the olives' consistency, degree of ripening, and crushing process (38).

Because of the presence of the oily fraction, the OMW tested had a viscous texture. This viscosity decreases with storage time. It formed a lipid layer on the surface of OMW, perhaps limiting natural evaporation.

According to the literature, the presence of fat matter allows the forming of a layer on the surface of the water, preventing proper oxygenation and light passage and obstructing the natural growth of flora and fauna within rivers. Soil bacteria that developed spores are inhibited by fatty acids and their derivatives. The decrease in lipid levels may be attributed to lipolysis, which eventually degraded fat during storage.

In addition, variations in suspended matter content can be attributed to climatic and geographical factors, botanical variations, the stage of olive ripening, and the oil extraction process (41). They were comparable to the results of D'Annibale et al. (21) (0.04-1.04\%). The TSS of OMW may be declined as a result of settling. This was most likely due to the effect of variety, maturity level, and agitation induced by the unloading of the OMW. The decrease in TSS level was probably due to the fermentation reaction and auto oxidation.

Also, for the water content, several researchers had comparable findings, including Kapellakis et al. (10) (83-92\%), Ouabou et al. (35) (88\%), Ouabou et al. (42) (86-87.6\%), and Noubigh et al. (8) (83-94\%). According to Nefzaoui (3), OMW was composed of 40 to $50 \%$ of vegetable water derived from the fruit and the remainder manufacturing water added during the crushing process. Procida and Ceccon (43) showed that the high humid- ity level of OMW was explained by the water present in the olives on the one side, and the water added during the olive oil extraction process on the other. The increase in humidity was caused by microbial activity, which produces water molecules as well as $\mathrm{H} 2$ and $\mathrm{CO}_{2}$ gases.

The obtained results for the dry matter were closer to those of Ouabou et al. (35) (138 g/L) and Ouabou et al. (42) (between 138.44 and $240 \mathrm{~g} / \mathrm{L})$. Variations in dry matter quality, according to El-Abbassi et al. (41), can be caused by climatic and geographical conditions, botanical variations, the stage of olive ripening, and the oil extraction process.

This decrease during the storage period was most probably due to matter deterioration caused by the microbial load in the vegetable water.

For the organic matter, the results obtained were superior to those obtained by Zaier et al. (23) (41.2-65.9 g/L) and closer to those obtained by Rajhi et al. (36) ( $89.59 \mathrm{~g} / \mathrm{L})$. The presence of macromolecules such as polysaccharides, lipids, proteins, and a variety of monocyclic and polymeric aromatic molecules was primarily responsible for the organic charge (20).

The slow degradation of macromolecules was responsible for the decrease in organic matter degradation rate. Microbial growth required energy, which was provided by organic molecule degradation.

The mineral matter results were consistent with those of Ouabou et al. (35) (24 g/L), Ouabou et al. (42) (22.69-24.35 $\mathrm{g} / \mathrm{L}$ ), and Belaid et al. (34) (10-25 g/L). The degree of ripening and the variety of olives illustrated the difference in mineral matter (41).

The slow decrease may be due to bacteria's inability to degrade it, as they require mineral elements to expand.

\section{Effect on volatile matter}

The gradual decrease in volatile matter could be due to bacteria, which can degrade many hydrocarbon substances such as organic acids, alcohols, sugars and polyholosides. These were closer to that observed by Zaier et al. (23) (49.7-81.4 g/L), Belaid et al. (34) (20-21.5 g/L), and Hamdi (37) (55 g/L). This difference was due to climatic conditions, olive oil extraction methods as well as the storage time of the olives before crushing (41).

The results of NTK were within the ranges reported by Capasso et al. (44) (1.2-2.4\%) and Kapellakis et al. (10) (1-3 g/L). This distinction may be attributed to the soil's natural abundance of nitrogen, which is retained in the fruit, or to the use of chemical fertilizers (45).

The continuous decrease is most possibly due to protein synthesis, which requires nitrogenous substances. The majority of bacteria obtain their nitrogen from other inorganic compounds (ammonia, ammonium salts, nitrites, nitrates) or from organic sources (amine group of organic compounds).

For the TCO $\%$, they were higher to those found by Belaid et al. (34) (13-15 g/L) and Mekki et al. (46) (17.6\%). These results were due to its richness by organic matter and the metabolism, which degraded and released it during $\mathrm{CO}_{2}$, ethanol and lactic 
acid reactions, further due to the polymerization.

The rise in the rate of $\mathrm{C} / \mathrm{N}$ is attributed to the samples' low biodegradable organic load and total organic carbon load.

The findings were closer to those found by Mekki et al. (46) (35.20) but lower than those obtained by (12). (50.50).

The results obtained for $\mathrm{BOD}_{5}$ are almost equivalent to those obtained by Zaier et al. (23) (65.87-86.71 g/L) and Ouabou et al. (42) (12.50-62.50 g/L). The presence of organic matter in the OMW was probably explained these high values.

This gradual decline during storage may be due to the microbial load and glucose metabolism, which releases gas, $\mathrm{CO}_{2}$, ATP, $\mathrm{H} 2$, alcohols, and $\mathrm{H}_{2} \mathrm{O}$, as well as the use of biologically degradable molecules such as $\mathrm{H}_{2} \mathrm{O}$ and $\mathrm{CO}_{2}$.

Moreover, for COD, several researchers had determined similar findings. Zaier et al. (23) measured 219.34-286.3 g/L, Ouabou et al. (42) measured 340-374 g/L, Hamimed et al. (47) measured $189.70 \mathrm{~g} / \mathrm{L}$, and Benamar et al. (14) measured 227.33 $\mathrm{g} / \mathrm{L}$. This decrease was caused by autoxidation and polymerization reactions, as well as the breakdown of recalcitrant molecules into biodegradable molecules or mineral compounds like $\mathrm{H}_{2} \mathrm{O}$ and $\mathrm{CO}_{2}$.

In addition, $\mathrm{BI}$ results fall within the range of the findings of Mekki et al. (46) (4) and Zaier et al. (23) (3.301-3.342). Moreover, it was lower than (4.48) that found by El-Rhaouat et al. (48). After one month of storage, we can concluded that even the OMW had a heavy organic load and was quickly biodegradable.

For TOM and $\mathrm{BOD}_{5} / \mathrm{COD}$ successively, the findings were higher than of those found by El-Rhaouat et al. (48) (TOM = $50.91 \mathrm{~g} / \mathrm{L})$ and $\left(\mathrm{BOD}_{5} / \mathrm{COD}=0.24\right)$.

Finally, based on the results of multivariate analysis (PCA), the biodegradability of OMW was probably due to the degradation of organic matter, which provided as a source of food for microorganisms that consume oxygen from the medium, which was becoming increasingly scarce (31).

\section{Conclusion}

Olive oil mill wastewater is one of the most important problems facing olive oil-producing countries. Since it is rejected without treatment, it causes damage to the environment because its characteristics are very important in the treatment of these effluents. The findings obtained during this study indicate that there is variability in the proportions of the effluent components of the two-variety study samples separated and combined. The storage time effect also indicates a very highly significant difference in the rate constituents of the same variety. The variability of the results obtained is due to a difference in the variety of olive, ripening stage, time, place and techniques of storage before the crash, duration and temperature of storage of OMW. The biodegradability of OMW is mainly due to the organic load rate, the microbial load, the acidity of the environment, the variety of olives, the storage conditions and the storage time. We find that OMW acidity increases in proportion to the storage time and is lowly biodegradable directly reduced with storage time, which includes the selection of the correct treatment process.

\section{Conflict of Interest}

The authors declare that they have no conflicts of interest.

\section{Ethical Compliance}

This article does not contain any studies involving human participants or animals performed by any of the authors.

\section{Acknowledgements}

We thank Drylands and Oases Cropping Laboratory, Institute of Arid Regions, Medenine, Tunisia for their technical assistance and support.

\section{References}

1. Alique D, Bruni G, Sanz R, Calles JA, Tosti S. Ultra-Pure Hydrogen via Co-Valorization of Olive Mill Wastewater and Bioethanol in Pd- Membrane Reactors. Processes. 2020;8(2):219.

2. Aggoun M, Arhab R, Cornu A, Portelli J, Barkat M, Graulet B. Olive mill wastewater microconstituents composition according to olive variety and extraction process. Food Chemistry. 2016;209:72-80.

3. Nefzaoui A. Contribution à la rentabilité de l'oléiculture par la valorisation optimale des sous-produits. Séminaire sur l'économie de l'olivier. Tunis. 1987;4:17-28.

4. Battista F, Mancini G, Ruggeri B, Fino D. Selection of the best pretreatment for hydrogen and bioethanol production from olive oil waste products. Renewable Energy. 2016;88:401-407.

5. Zenjari B, El-Hajjouji H, Ait-Baddi G, Bailly JR, Revel JC, Nejmeddine A, Hafidi M. Eliminating toxic compounds by composting of olive mill wastewater straw mixture. J. Hazardous Mater. 2006;138:433-437.

6. Hocaoglu SM, Gursoy BH, Basturk I, Talazan P, Aydoner C. Assessment of technology modification for olive oil sector through mass balance: A case study for Turkey. Journal Cleaner Prod. 2018;188:786-795.

7. Genç N, Durna E, Cicigün HKK. Response Surface Modeling and Optimization of Microwave-Activated Persulfate Oxidation of Olive Oil Mill Wastewater. Clean - Soil, Air, Water. 2020;48:1900198.

8. Noubigh A, Abderrabba M, Provost E. Temperature and addition effects on the solubility behaviour of some phenolic compounds in water. Jouranl of Chemical Thermodynamics. 2007;39:297-303.

9. Achak M, Ouazzani N, Mandi L. Élimination des polluants organiques des effluents de l'industrie oléicole par combinaison d'un filtre à sable et un lit planté. Revue des Sciences de l'Eau. $2011 ; 24: 35-51$.

10. Kapellakis IE, Tsagarakis KP, Crowther JC. Olive oil history, production and by-product management. Reviews in Environmental Science and Bio/Technology. 2008;7:1-26.

11. Mohawesh O, Al-Hamaiedeh H, Albalasmeh A, Qaraleh S, Haddadin M. Effect of olive mill wastewater (OMW) 
application on soil properties and wheat growth performance under rain-fed conditions. Water Air Soil Pollution. 2019;230:160.

12. El-Hajjouji H. Evolution des caractéristiques physico-chimiques, spectroscopiques et écotoxicologiques des effluents d'huileries d'olive au cours de traitements biologique et chimique. Thèse de doctorat. Institut national polytechnique de Toulouse. École doctorale : Sciences Écologiques, Vétérinaires. Agronomiques et Bioingénieries Spécialité : Ecologie et Agrosystèmes. 2007;163.

13. Ntougias S, Gaitis F, Katsaris P, Skoulika S, Iliopoulos N, Zervakis GI. The effects of olives harvest period and production year on olive mill wastewater properties - evaluation of Pleurotus strains as bioindicators of the effluent's toxicity. Chemosphere. 2013;92:399-405.

14. Benamar A, Mahjoubi FZ, Barka N, Kzaiber F, Boutoial K, Gomaa AM, Oussama A. Olive mill wastewater treatment using infiltration percolation in column followed by aerobic biological treatment. SN Applied Sciences. 2020;2:655.

15. Ouedrhini W, Mounyr B, Harki E, Moja S, Greche H. Synergistic antimicrobial activity of two binary combination of marjoram, lavender, and wild thyme essential oils. International Journal of Food Properties. 2017;20:3149-3158.

16. Esmail A, Abed H, Firdaous M, Chahboun N, Mennane Z, Berny EH, Ouhssine M. Étude physico-chimique et microbiologique des margines de trois régions du Maroc. (Ouazzane, Fès Boulman et Béni Mellal). J. Mater. Environ. Sci. 2014;5:121-126.

17. Mikdame H, Kharmach E, Mtarfi NE, Alaoui K, Ben Abbou M, Rokni Y, Majbar Z, Taleb M, Rais Z. By-Products of Olive Oil in the Service of the Deficiency of Food Antioxidants: The Case of Butter. Journal of Food Quality. 2020;1:1-10.

18. Lakhtar $\mathrm{H}$, Ismaili-Alaoui $\mathrm{M}$, Philippoussis A, Perraud-Gaime I, Roussos S. Screening of strains of Lentinula edodes grown on model olive mill wastewater in solid and liquid state culture for polyphenol biodegradation. International Biodeterioration and Biodegradation. 2010;64:167-172.

19. Ranalli A. L'effluent des huileries d'olive : Propositions en vue de son épuration. Références aux normes italiennes en la matière. Première partie. Olivae. 1991;37:30-39.

20. Aissam H. Etude de la biodégradation des effluents des huileries (margines) et leur valorisation par production de l'enzyme tannase. Thèse de doctorat, Faculté des sciences. Dhar El Mehraz, Fes. 2003.

21. D’Annibale A, Federici F, Fenice M, Sermanni GG, Pet+ruccioli M, Vassilev N. Residues of olive oil extraction process: possible biotechnological approach. Science and technology. 2003;85:1-4.

22. Achak M, Ouazzani N, Yaacoubi A, Mandi L. Caractérisation des margines issues d'une huilerie moderne et essais de leur traitement par coagulation floculation par la chaux et le sulfate d'aluminium. Revue des Sciences de l'Eau. 2008;21:53-67.
23. Zaier H, Chmingui W, Rajhi H, Bouzidi D, Roussos S, Rhouma A. Caractérisation physico-chimique et microbiologique des margines de différentes régions de la Tunisie (Nord, Sahel, Sud). Journal of New Sciences. 2017;48:E-ISSN 2286-5314.

24. Rodier J. Lanalyse de l'eau : eaux naturelles, eaux résiduaires, eaux de mer. Huitième édition DUNOD Paris. $1996 ; 1384$.

25. Gortzi O, Lalas S, Chatzilazarou A, Katsoyannos E, Papaconstandinou S, Dourtoglou E. Recovery of Natural Antioxidants from olive mill wastewater using genapol-X080. Journal of the American Oil Chemists'Society. 2008;85:133-140.

26. Assas N, Marouani L, Hamidi M. Scale down and optimization of olive mill wastewaters decolorization by Geotricum candidum. Bioprocess Engineering. 2000;22:503-507.

27. Pauwels JM, Van-Ranst E, Verloo M, Mvendo ZEA. Manuel de laboratoire de pédologie. Méthodes d'analyses des sols et des plantes, équipements, gestion de stocks de verrerie et de produits chimiques. Bruxelles: Administration Générale de la Coopération au Développement (AGCD). 1992.

28. AFNOR, Norme T90-1110. Essai des eaux : dosage de l'azote total Kjeldahl. 1975.

29. AFNOR, Recueil de normes françaises : eau, méthodes d’essai, 2éme édition, Paris, France. 1983;621.

30. Radoux M, Cadelli D. Epuration extensive des eaux usées des petites collectivités en zones rurales. Smmarcelli-Biguglia. 1995;7:45-52.

31. Bassirou A. Impact des rejets de la ville de Niamey (Niger) sur la qualité des eaux du fleuve Niger. Thèse de Doctorat. Facultés universitaires Notre-Dame de la paix Namur. 2007;230.

32. Bustamante MA, Said-Pullicino D, Paredes C, Cecilia JA, Moral R. Influences of winery-distillery waste compost stability and soil type on soil carbon dynamics in amended soils. Waste Management. 2010;30:1966-1975.

33. De Felice B, Pontecorvo G, Carfagna M. Degradation of waste waters from olive oil mills by Yarrowia lipolytica ATCC 20255 and pseudomonas pitida. Acta Biotechnol. 1997;17:231-239.

34. Belaid C, Kallel M, Elleuch B. Identification de nouveaux composés phénoliques présents dans les rejets liquides d'huileries d'olive (margines). Revue Francophone d'Ecologie Industrielle. 2002;27.

35. Ouabou E, Anouar A, Hilali S. Elimination des polluants organiques présents dans la margine d'huile d'olive par filtration sur colonne d'argile et sciure de bois d'eucalyptus. Journal of Applied Biosciences. 2014a;75:6232-6238.

36. Rajhi H, Mnif I, Abichou M, Rhouma A. Assessment and valorization of treated and non-treated olive mill wastewater (OMW) in the dry region. Int. J. Recycl. Org. Waste Agricult. 2018;7:199-210.

37. Hamdi M. Valorisation et épuration des effluents des huileries d’olives: l'utilité de la microbiologie industrielle. Oli- 
vae. 1993;46:20-24.

38. Amaral C, Marco SL, Joaõ C, Antonio L, Cresp I, Maria A, Célia P. Microbiological and physicochemical characterization of olive mill wastewaters from a continuous olive mill in Northeastern Portugal. Bioresource Technology. 2008;99:7215-7223.

39. Hamdi M. Effects of agitation and pretreatment on the batch anaerobic digestion of olive mill wastewater. Bioresource Technology. 1991;36:173-178.

40. Assas N, Ayed L, Marouani L, Hamdi M. Decolorization of fresh and stored and stored-black olive mill wastewaters by Geotrichum candidum. Process Biochemistry. 2002;38:361-365.

41. El-Abbassi A, Khayet M, Hafidi A. Micellar enhanced ultrafiltration process for the treatment of olive mill wastewater. Water Research. 2011;45:4522-4530.

42. Ouabou E, Anouar A, Hilali S. Traitement de la margine brute d'huile d'olive par distillation suivi de neutralisation par la chaux. Journal of Applied Biosciences. 2014b;79:6867-6872.

43. Procida G, Ceccon L. Gas chromatographic determination of free fatty acids in olive mill waste waters. Analytical Chimica Acta. 2006;561:103-106.

44. Capasso R, De Martino A, Arienzo M. Recovery and characterization of the metal polymeric organic fraction (polymerin) from olive oil mill wastewaters. J Agric Food Chem. 2002;50:2846-2855.

45. Zenjari I. Etude écotoxicologique des effluents liquides des huileries de la ville de Marrakech, impact sur les milieux récepteurs et détoxication. Thèse de Doctorat. Faculté des Sciences Semlalia, université Cadi Ayyad, Marrakech, Maroc. 2000;149.

46. Mekki A, Dhouib A, Aloui F, Sayadi S. Olive wastewater as an ecological fertilizer. Agronomy for Sustainable Development. Springer Verlag/EDP Sciences/INRA. 2006;26:61-67.

47. Hamimed S, Jebli N, Sellami H, Landoulsi A, Chatti A. Dual Valorization of Olive Mill Wastewater by Bio-Nanosynthesis of Magnesium Oxide and Yarrowia lipolytica Biomass Production. Chem Biodiversity. 2020;17:e1900608.

48. El Rhaouat O, Fareh M, Sarhan B, Benyouf S, Chiguer H, Rochdi M, Ould Abdlkader C, El Kharrim K, Belghyti D. Etude statistique et physico-chimique des margines d'extraction d'huile d'olive de la ville Sidi Kacem. International Journal of Innovation and Applied Studies. 2014;9:757764 . 